\title{
Statin use and non-melanoma skin cancer risk: a meta-analysis of randomized controlled trials and observational studies
}

\author{
Keming Yang ${ }^{1}$, Andrew Marley ${ }^{1}$, Huilin Tang ${ }^{1}$, Yiqing Song ${ }^{1}$, Jean Y. Tang ${ }^{2}$ and Jiali \\ Han $^{1}$ \\ ${ }^{1}$ Department of Epidemiology, Richard M. Fairbanks School of Public Health, Indiana University, Indianapolis, IN 46202-2872, USA \\ ${ }^{2}$ Department of Dermatology, Stanford University School of Medicine, Stanford, CA 94063, USA
}

Correspondence to: Jiali Han, email: jialhan@iu.edu

Keywords: statins, non-melanoma skin cancer, meta-analysis

Received: June 26, $2017 \quad$ Accepted: July 26, $2017 \quad$ Published: August 08, 2017

Copyright: Yang et al. This is an open-access article distributed under the terms of the Creative Commons Attribution License 3.0 (CC BY 3.0), which permits unrestricted use, distribution, and reproduction in any medium, provided the original author and source are credited.

\section{ABSTRACT}

Background: Existing evidence of the association between statin use and nonmelanoma skin cancer (NMSC) risk has been inconsistent.

Objective: To maximize statistical power to synthesize prospective evidence on this relationship.

Materials and Methods: PubMed, EMBASE, Web of Science, Cochrane Central Register of Controlled Trials, and ClinicalTrial.gov were systematically searched up to December 11, 2016. A random-effects meta-analysis was conducted to calculate summary estimates.

Results: Our meta-analysis of 14 randomized controlled trials (RCTs) including 63,157 subjects showed no significant association between statin use and NMSC risk $(R R=1.09,95 \% C I=0.85-1.39)$. However, meta-analysis of four observational studies including 1,528,215 participants showed significantly increased risk of NMSC among statin users compared to non-users $(R R=1.11,95 \% C I=1.02-1.22)$. Furthermore, ever using lipophilic statins $(R R=1.14,95 \% C I=1.04-1.24)$ or lowerpotency statins $(\mathrm{RR}=1.14,95 \% \mathrm{CI}=1.03-1.26)$, as well as usage of any statin longer than one year $(R R=1.14,95 \% C I=1.09-1.18)$ were significantly associated with increased NMSC risk based on observational studies.

Conclusions: Evidence from observational studies supported an association between statin use and increased NMSC risk. This finding should be interpreted with caution due to modest number of included studies, possible between-study heterogeneity and inherent limitations of observational studies.

\section{INTRODUCTION}

Non-melanoma skin cancer (NMSC), including basal cell carcinoma (BCC) and squamous cell carcinoma (SCC) of the skin, is the most common cancer in the United States [1, 2]. Statins (HMG-CoA reductase inhibitors), potent cholesterol-lowering medications, have proven effective in the prevention of adverse cardiovascular events. Moreover, some studies also indicated a potential chemopreventive action of statins against overall cancer risk [3], as well as risks of cancers such as gastric [4], colorectal [5], breast [6], and prostate cancers [7]. However, evidence for risk of NMSC has been conflicting. Compared to controls, more NMSC cases were observed among the treatment group in some large randomized controlled trials (RCTs) of statins such as the Scandinavian Simvastatin Survival Study (4S) [8] and the Heart Protection Study (HPS) [9], but not others [10-12]. One previous meta-analysis found no significant association between statins and skin cancer[13]. A few prospective observational studies have specifically examined this hypothesis. Recently, Wang et al. [14] found that statins were associated with increased NMSC risk in the Women's Health Initiative (WHI) cohort. A nested 
case-control study using Denmark national registries data also identified a significant association between statin use and slightly increased risk of BCC but not SCC [15]. Therefore, to maximize statistical power to synthesize prospective evidence on the relationship between statin use and NMSC risk, we conducted this meta-analysis of all eligible prospective observational studies and randomized controlled trials.

\section{RESULTS}

\section{Study selection and study characteristics}

Among the 6,420 citations retrieved from the electronic databases, a total of seven reports that covered 14 RCTs including 63,157 subjects and 1,211 NMSC events $[8-12,16,17]$, as well as four observational studies including 1,528,215 participants and 55,793 NMSC cases $[14,15,18,19]$ met our eligibility criteria and were included in this meta-analysis. The mean duration of included RCTs varied from 2 to 5.4 years while the mean/ median follow-up time of included cohort studies varied from 3.5 to 10.5 years. A diagram of the study selection process is shown in Figure 1; basic characteristics of all included studies are shown in Table 1, and quality assessment results are shown in Supplementary Table 1.

\section{Meta-analysis of statin use and NMSC risk}

Meta-analysis of RCTs did not show a significant association between statin use and NMSC risk $(\mathrm{RR}=1.09$, $95 \% \mathrm{CI}=0.85-1.39 ; \mathrm{I}^{2}=59.9 \% ; P$ for heterogeneity $=$ 0.02 ). However, the meta-analysis of observational studies revealed a significant association. Statin users have a

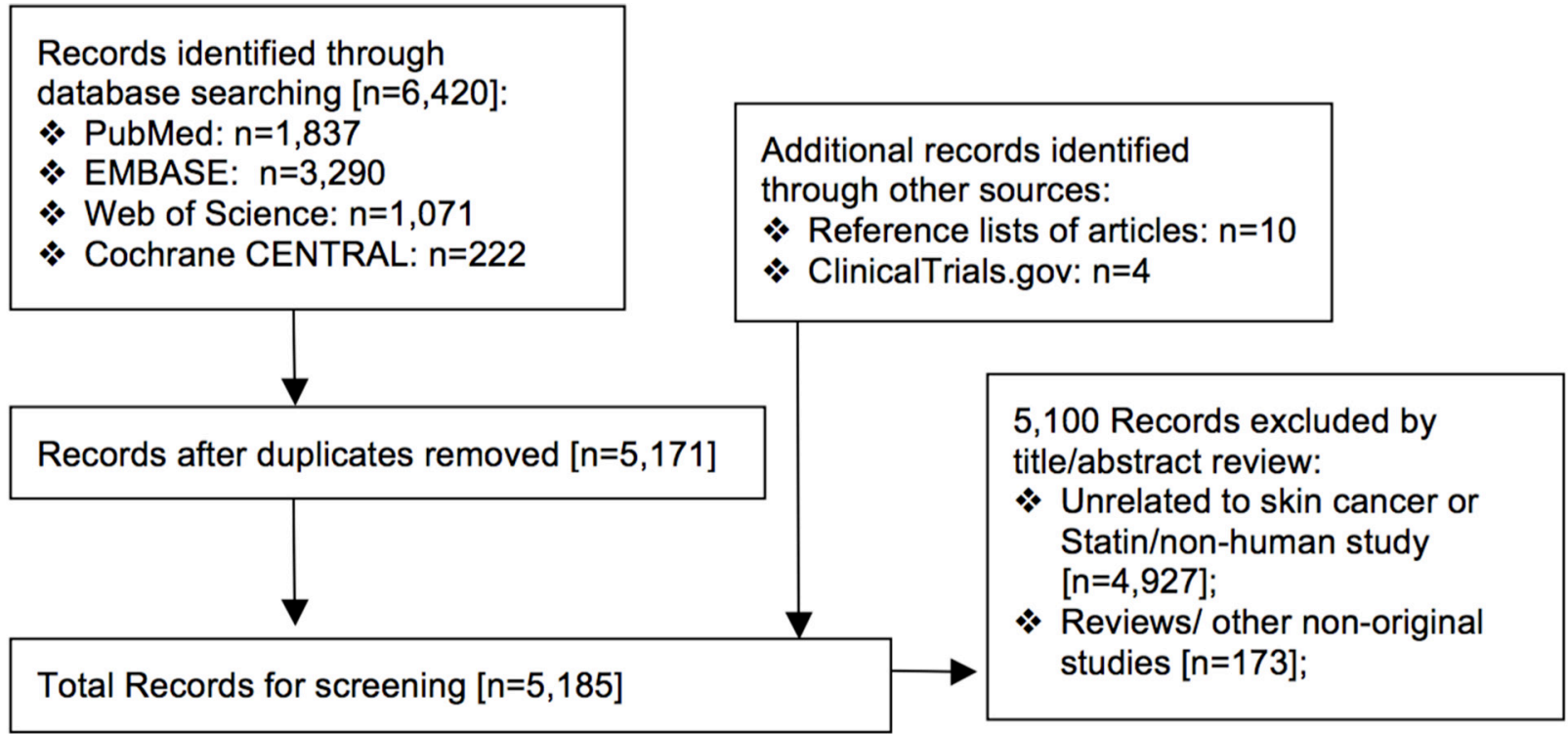

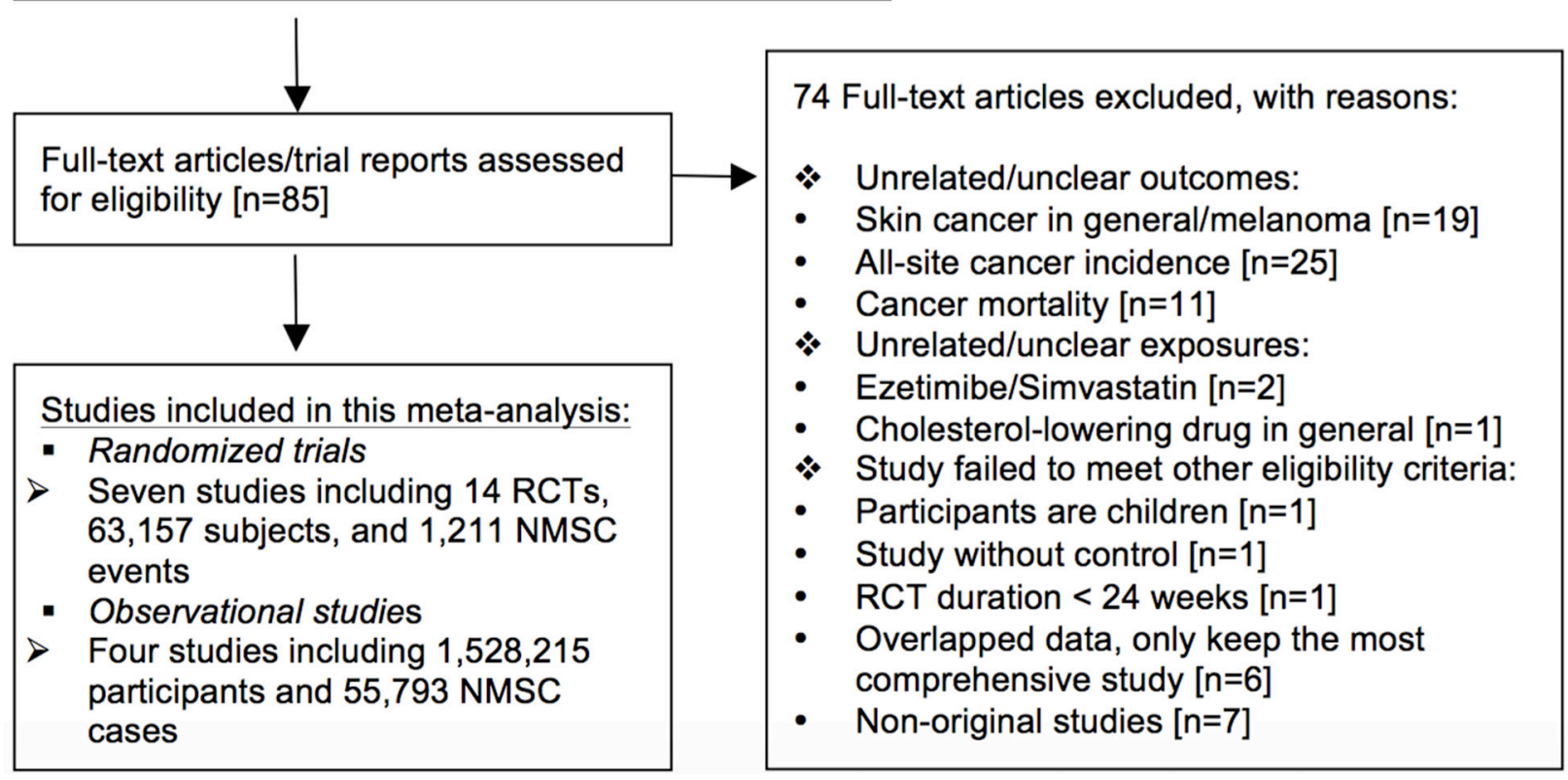

Figure 1: Flow chart of study selection. 
Table 1: Characteristics of included studies in this meta-analysis

\begin{tabular}{|c|c|c|c|c|c|c|c|c|c|c|c|c|}
\hline \multicolumn{13}{|c|}{ Randomized trials } \\
\hline $\begin{array}{l}\text { Report } \\
\text { year }\end{array}$ & \multicolumn{2}{|l|}{ Trial Name } & Study Design & $\begin{array}{l}\text { Study } \\
\text { Location }\end{array}$ & $\begin{array}{l}\text { Mean } \\
\text { Duration of } \\
\text { exposure }\end{array}$ & Statins type (dose) & $\begin{array}{l}\text { Treatment } \\
\text { (NMSC cases/ } \\
\text { participants) }\end{array}$ & $\begin{array}{l}\text { Control } \\
\text { (NMSC cases } \\
\text { /participants }\end{array}$ & \multicolumn{2}{|l|}{ Age\#\# } & Men & White \\
\hline 1994 & $4 \mathrm{~S}$ & & RCT & $\begin{array}{l}5 \\
\text { European } \\
\text { countries }^{\#}\end{array}$ & 5.4 years & $\mathrm{S}(20-40 \mathrm{mg} /$ day $)$ & $13 / 2221$ & $6 / 2223$ & \multicolumn{2}{|l|}{$35-70$} & 0.81 & NR \\
\hline 2000 & GISSI & & RCT & Italy & 2 years & $\mathrm{P}(20 \mathrm{mg} /$ day $)$ & $1 / 2138$ & $1 / 2133$ & \multicolumn{2}{|l|}{$\begin{array}{l}\text { C: } 60.0 \pm 10.4, \\
\text { T: } 59.7 \pm 10.4\end{array}$} & 0.86 & NR \\
\hline 2001 & $\begin{array}{l}\text { AFCAPS } \\
\text { /TexCAPS }\end{array}$ & & $\mathrm{RCT}$ & USA & 5.2 years & $\mathrm{L}(20-40 \mathrm{mg} /$ day $)$ & $250 / 3304$ & $243 / 3301$ & \multicolumn{2}{|l|}{$45-73$} & 0.85 & NR \\
\hline 2005 & HPS & & $\mathrm{RCT}$ & UK & 5.3 years & $\mathrm{S}$ (40 mg/day) & $243 / 10269$ & $202 / 10267$ & \multicolumn{2}{|l|}{$64.0 \pm 8.4$} & 0.75 & NR \\
\hline 2006 & $\begin{array}{l}\text { ALERT,FLAR } \\
\text { SA,NDA95 stu }\end{array}$ & $\begin{array}{l}\text { AS,LIPS,Li } \\
-3\end{array}$ & $\begin{array}{l}\text { Pooled analysis } \\
\text { of } 8 \text { RCTs }\end{array}$ & Variable & 2.4 years & $\mathrm{F}(20-80 \mathrm{mg} /$ day $)$ & $103 / 3512$ & $125 / 3289$ & \multicolumn{2}{|l|}{$\begin{array}{l}\text { C: } 55.8 \pm 11.0 \\
\text { T: } 55.1 \pm 11.3\end{array}$} & 0.72 & 0.96 \\
\hline 2011 & JUPITER & & RCT & USA & 2 years & $\mathrm{R}$ (20mg/day) & $15 / 8869$ & $5 / 8864$ & \multicolumn{2}{|l|}{$66.1 \pm 7.72$} & 0.62 & NR \\
\hline 2014 & AURORA & & $\mathrm{RCT}$ & $\begin{array}{l}\text { Europe, } \\
\text { America, } \\
\text { Asia }\end{array}$ & 2.4 years & $\mathrm{R}$ (10mg/day) & $1 / 1389$ & $3 / 1378$ & \multicolumn{2}{|l|}{$64.2 \pm 8.6$} & 0.62 & 0.85 \\
\hline \multicolumn{13}{|c|}{ Observational study (cohort and nested case-control studies) } \\
\hline $\begin{array}{l}\text { Publication } \\
\text { year }\end{array}$ & First Author & $\begin{array}{l}\text { Study } \\
\text { Design }\end{array}$ & $\begin{array}{l}\text { Study Location } \\
\text { (data source) }\end{array}$ & $\begin{array}{l}\text { Follow- } \\
\text { up time }\end{array}$ & $\begin{array}{l}\text { Exposure } \\
\text { ascertainment }\end{array}$ & $\begin{array}{l}\text { Outcome } \\
\text { assessment }\end{array}$ & Statins type & $\begin{array}{l}\text { Sample } \\
\text { size }\end{array}$ & $\begin{array}{l}\text { Adjusted RR } \\
\text { (any use vs. no } \\
\text { use) }\end{array}$ & Age & Men & White \\
\hline 2016 & Wang & Cohort & $\begin{array}{l}\text { USA (WHI } \\
\text { OS+CT) }\end{array}$ & $\begin{array}{l}\text { Mean: } \\
10.5 \text { yrs }\end{array}$ & $\begin{array}{l}\text { Self-report } \\
\text { (medication } \\
\text { containers) }\end{array}$ & Self-report & $\mathrm{S}, \mathrm{L}, \mathrm{P}, \mathrm{F}, \mathrm{A}, \mathrm{C}, \mathrm{R}$ & 118,357 & $1.21(1.07-1.35)$ & $50-79$ & 0 & 1 \\
\hline 2015 & Arnspang & $\begin{array}{l}\text { Nest case- } \\
\text { control }\end{array}$ & $\begin{array}{l}\text { Denmark } \\
\text { (Nationwide } \\
\text { registries) }\end{array}$ & $\geq 1$ year $^{\Delta}$ & $\begin{array}{l}\text { Prescription } \\
\text { registry }\end{array}$ & Cancer Registry & S,L,P,F,A,C,R & 464,288 & $\begin{array}{l}\text { BCC: } 1.09(1.06- \\
1.13) ; \text { SCC: } 1.01 \\
(0.91-1.11)\end{array}$ & NR & NR & $\sim 1$ \\
\hline 2009 & Haukka & $\begin{array}{l}\text { Cohort- } \\
\text { record } \\
\text { linkage }\end{array}$ & $\begin{array}{l}\text { Finland } \\
\text { (Nationwide } \\
\text { registries) }\end{array}$ & $\begin{array}{l}\text { Mean: } \\
8.8 \text { yrs }\end{array}$ & $\begin{array}{l}\text { Prescription } \\
\text { registry }\end{array}$ & Cancer Registry & $\mathrm{S}, \mathrm{L}, \mathrm{P}, \mathrm{F}, \mathrm{A}, \mathrm{C}, \mathrm{R}$ & 944,962 & $1.28(1.16-1.41)$ & $\begin{array}{l}\text { Median: } \\
60\end{array}$ & 0.5 & NR \\
\hline 2009 & Dore & $\begin{array}{l}\text { Cohort- } \\
\text { record } \\
\text { linkage }\end{array}$ & $\begin{array}{l}\text { USA } \\
\text { (VATTC trial)** }^{* *}\end{array}$ & $\begin{array}{l}\text { Median: } \\
3.5 \text { yrs }\end{array}$ & $\begin{array}{l}\text { Pharmacy } \\
\text { Benefits } \\
\text { Management } \\
\text { database }\end{array}$ & $\begin{array}{l}\text { Physical } \\
\text { examinations }+ \\
\text { biopsy }\end{array}$ & $\mathrm{S}, \mathrm{L}, \mathrm{P}, \mathrm{F}, \mathrm{A}$ & 608 & $0.92(0.73-1.16)$ & $\begin{array}{l}90 \% \\
>60\end{array}$ & 0.98 & 0.99 \\
\hline
\end{tabular}

Note: 1. Full name of trials: 4S: Scandinavian Simvastatin Survival Study; GISSI: Gruppo Italiano per lo Studio della Sopravvivenza nell'Infarto Miocardico(Italian group for the study of the survival of Myocardial Infarction); AFCAPS/TexCAPS: Air Force/Texas Coronary Atherosclerosis Prevention Study; HPS: Heart Protection Study; ALERT: Assessment of LEscol in Renal Transplantation; FLARE: FLuvastatin Angiographic REstenosis trial; LCAS: Lipoprotein and Cholesterol Atherosclerosis Study; LIPS: Lescol Intervention Prevention Study; LiSA: Lescol in Severe Atherosclerosis trial; NDA95: new drug application studies; JUPITER: The Justification for the Use of Statins in Prevention: An Intervention Trial Evaluating Rosuvastatin (JUPITER) Trial; AURORA: A Study to Evaluate the Use of Rosuvastatin in Subjects on Regular Hemodialysis: An Assessment of Survival and Cardiovascular Events; 2. Abbreviations of statins: F: Fluvastatin; L: Lovastatin; P: Pravastatin; S: Simvastatin; R: Rosuvastatin; A: Atorvastatin; C: Cerivastatin; 3. NR: not reported; \# Five European countries: Denmark, Finland, Iceland, Norway, Sweden; \#\# Age was shown in range or mean \pm standard deviation, C: control, T: treatment; * WHI OS+CT: Women's Health Initiative (WHI) Observational Study (OS) and Clinical Trial (CT); ** VATTC: Veterans Affairs Topical Tretinoin Chemoprevention Trial; ${ }^{\wedge}$ : Incident NMSC during 2005-2009; Prescription: 1995 to 1 year before diagnosis; : Approximately;

higher risk of NMSC than non-users $(\mathrm{RR}=1.11,95 \% \mathrm{CI}$ $=1.02-1.22 ; I^{2}=76.8 \% ; P$ for heterogeneity $\left.=0.002\right)($ See Figure 2). Begg's and Egger's tests showed no significant evidence of publication bias (meta-analysis of RCTs: $P$ for Begg's test $=0.88, P$ for Egger's test $=0.70$; meta-analysis of observational studies: $P$ for Begg's test $=0.62, P$ for Egger's test $=0.84$ ).

\section{Subgroup analysis of statin use and NMSC risk}

The results of subgroup analyses are shown in Table 2. Between-group heterogeneity was not statistically significant in most subgroups $(P>0.05)$. None of the subgroup analyses detected a significant association based on RCTs $(P>0.05)$. However, subgroup analyses of observational studies revealed significantly increased risks of NMSC among ever-users of lipophilic statins (RR $=1.14,95 \% \mathrm{CI}=1.04-1.24)$ or statins with lower potency $(\mathrm{RR}=1.14,95 \% \mathrm{CI}=1.03-1.26)$, compared to neverusers. Additionally, users of statins for more than one year had significantly higher NMSC risk than never-users (RR $=1.14,95 \% \mathrm{CI}=1.09-1.18$ ).

\section{DISCUSSION}

Our meta-analysis of four prospective observational studies involving 1,528,215 participants and 55,793 NMSC cases suggested a significant and positive association between statins and NMSC risk. However, our meta-analysis of 14 RCTs with 63,157 participants and 1,211 NMSC events did not observe such an 
Table 2: Meta-analysis and subgroup analysis of randomized trials and observational studies

\begin{tabular}{|c|c|c|c|c|c|c|c|c|c|}
\hline & \multirow{3}{*}{$\begin{array}{c}\text { Subgroup } \\
\text { analyses }\end{array}$} & \multicolumn{4}{|c|}{ RCTs } & \multicolumn{4}{|c|}{ Observational Studies } \\
\hline & & \multirow{2}{*}{$\begin{array}{l}\text { No. of } \\
\text { studies }\end{array}$} & \multirow{2}{*}{ RR $(95 \% C I)$} & \multicolumn{2}{|c|}{ Heterogeneity } & \multirow{2}{*}{$\begin{array}{l}\text { No. of } \\
\text { studies }\end{array}$} & \multirow{2}{*}{ RR $(95 \% C I)$} & \multicolumn{2}{|c|}{ Heterogeneity } \\
\hline & & & & $\mathbf{I}^{2}$ & $P$ & & & $I^{2}$ & $P$ \\
\hline Total & & 7 & $1.09(0.85-1.39)$ & $59.9 \%$ & 0.02 & 4 & $1.11(1.02-1.22)$ & $76.8 \%$ & 0.002 \\
\hline \multirow[t]{2}{*}{ By Category } & Lipophilic & $4(s, f, l)$ & $1.04(0.82-1.31)$ & $69.5 \%$ & 0.02 & $2(s, f, 1 . a)$ & $1.14(1.04-1.24)$ & $36.5 \%$ & 0.10 \\
\hline & Hydrophilic & $3(r, p)$ & $1.39(0.35-5.55)$ & $39.1 \%$ & 0.19 & $2(p)$ & $0.96(0.81-1.15)$ & $0.0 \%$ & 0.70 \\
\hline \multirow[t]{2}{*}{ By Potency } & Lower & 5 (f,l.s.p) & $1.04(0.83-1.30)$ & $57.3 \%$ & 0.05 & 2 (f,1.s.p) & $1.14(1.03-1.26)$ & $39.0 \%$ & 0.08 \\
\hline & Higher & $2(r)$ & $1.27(0.15-10.46)$ & $67.1 \%$ & 0.08 & 2 (a) & $1.05(0.94-1.17)$ & $0.0 \%$ & 0.55 \\
\hline \multirow[t]{5}{*}{ By Duration } & $<5$ years & 4 & $1.08(0.43-2.71)$ & $58.2 \%$ & 0.07 & 3 & $\begin{array}{c}<1 \text { year: } 1.08 \\
(0.99-1.18)\end{array}$ & $39.0 \%$ & 0.16 \\
\hline & & & & & & 3 & $\begin{array}{c}\geq 1 \text { year: } 1.14 \\
(1.09-1.18)\end{array}$ & $30.8 \%$ & 0.13 \\
\hline & & & & & & 3 & $\begin{array}{c}1-<3 \text { years: } 1.14 \\
(1.04-1.25)\end{array}$ & $47.9 \%$ & 0.10 \\
\hline & & & & & & 3 & $\begin{array}{c}3-<5 \text { years: } 1.14 \\
(1.08-1.20)\end{array}$ & $0.0 \%$ & 0.67 \\
\hline & $\geq 5$ years & 3 & $1.14(0.94-1.37)$ & $40.4 \%$ & 0.19 & 3 & $\begin{array}{c}\geq 5 \text { years: } 1.16 \\
(1.04-1.29)\end{array}$ & $55.7 \%$ & 0.08 \\
\hline
\end{tabular}

Note: s: Simvastain, f: Fluvastain, 1: Lovastatin, r: Rosuvastatin, p: Pravastatin, a: Atorvastatin; Comparisons were conducted between any use and no use of statins (or statins of different type);

association. This may be due to the fact that RCTs usually have shorter follow-up period of time than observational studies and an increased risk of rare events (e.g. cancers) may not be detected during a relatively short duration. Besides, cancer events are not the primary endpoints of the RCTs for statins. Therefore, observational studies

RR $(95 \% \mathrm{Cl}) \quad$ Weight $\%$

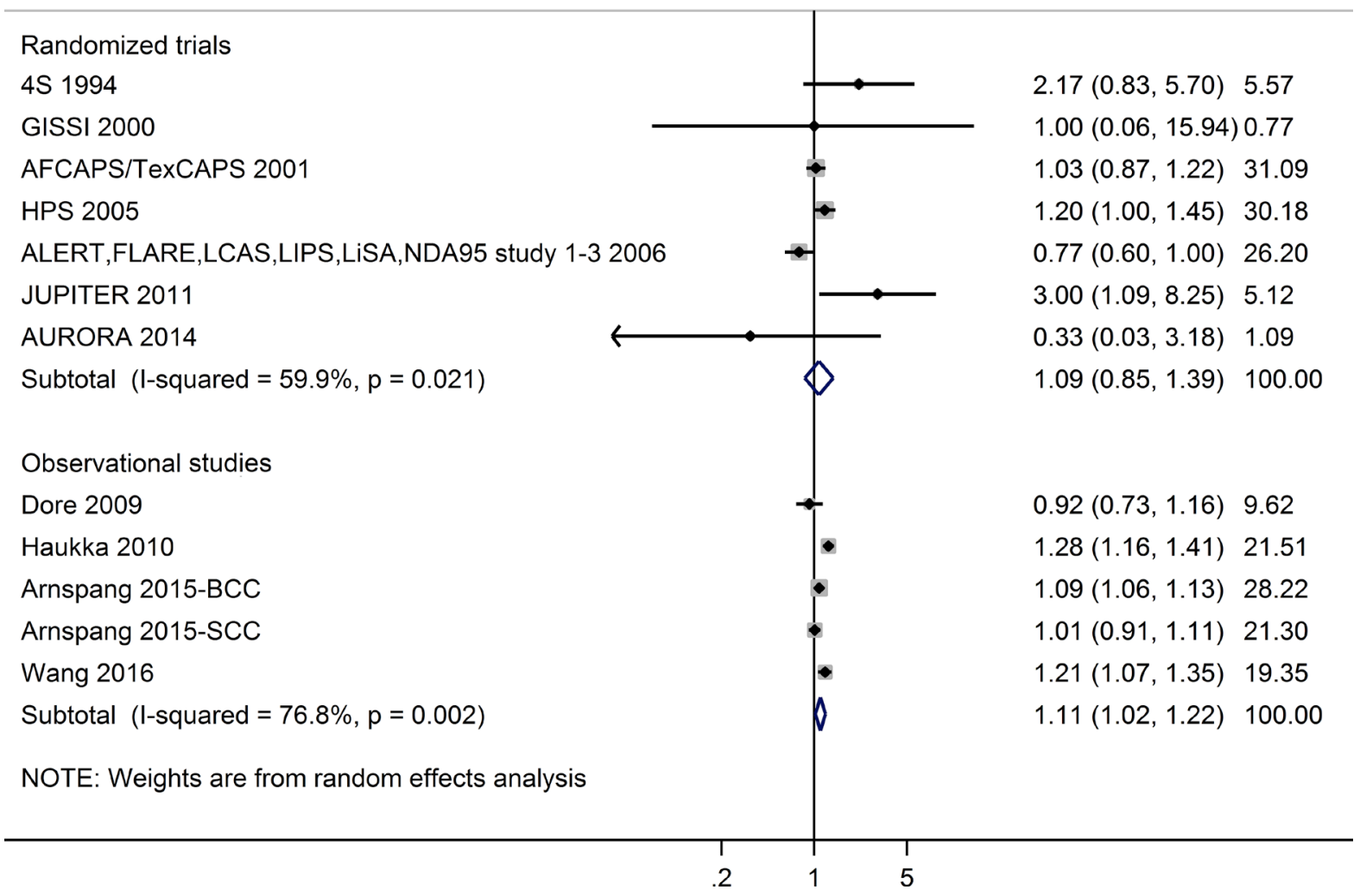

Figure 2: Forest plot: meta-analysis of statin use and non-melanoma skin cancer risk. 
may have some advantage of examining a long-term drug-safety issue.

One previous meta-analysis evaluated statins and all-cancer risk, among which only four RCTs were related to NMSC, and their pooled results indicated a significant association between statins and increased NMSC risk [20]. Another meta-analysis conducted by Li et al. [13] found no significant association between statins and risk of either melanoma or NMSC. However, that study also included skin cancer cases of unspecified type in the meta-analysis of NMSC. To our knowledge, ours is the first metaanalysis specifically examining the relationship between the risk of NMSC and statins, as well as statins of different potency, category, and duration of use.

Melanoma, SCC, and BCC are three major types of skin cancer. The underlying mechanisms of melanoma and non-melanoma skin cancers (SCC and BCC) are not the same. In terms of melanoma, which is the most serious type of skin cancer, most randomized controlled trials and observational studies published so far showed nonsignificant association between statin use and melanoma risk [13]. Recently, sixteen years of follow-up of the Longterm Intervention with Pravastatin in Ischemic Disease (LIPID) trial also reported no excess cases of melanoma in the intervention group, compared to the control group [21].

We still lack substantial understanding of the biological mechanisms by which statins affect cancer risk, and whether specific properties of statins make any difference in this process. Some studies have indicated that the immunomodulatory effects of statins may be responsible for its potential carcinogenic actions. A statininduced increase in $\mathrm{CD} 4+\mathrm{CD} 25+$ regulatory $\mathrm{T}$ cells (Tregs) may impair the host antitumor immune response through suppressing the tumor specific effector $\mathrm{T}$ cell response, which may lead to an increased risk of cancer [22]. Notably, immunosuppression is an emerging risk factor for NMSC [23], and may explain the high incidence of NMSC in the elderly populations who are susceptible to immunosenescence. In addition, immunosuppressant therapies constitute a major risk factor of developing post-transplantation skin cancers among organ transplant recipients [24]. In kidney transplant recipients, high Tregs levels within the peripheral circulation were associated with new SCC development [25]. On the contrary, some research has also suggested that statins exert a protective action against skin cancers by inhibiting the mevalonate and hedgehog signaling pathways, disrupting cancer cell growth and inducing keratinocyte apoptosis [26]. As statins have also been associated with reduced risks of several other types of cancers $[7,20]$, it is possible that statins may play roles in affecting different cancer risks through various biological pathways.

Our findings should be interpreted with caution due to the modest number of studies we were able to include, possible between-study heterogeneity, as well as the residual confounding inherent in observational studies. Due to the unavailability of original data, we could not conduct meta-analysis separately for BCC and SCC. We also could not estimate dose-response effects as available data were too heterogeneous to pool.

In conclusion, our meta-analysis of observational studies supported an association between statin use and increased NMSC risk. In future, ongoing post-marketing surveillance and long-term follow-up studies of RCTs could provide ongoing monitoring of new NMSC cases that may be related to the use of statins. More prospective studies with large sample sizes could be conducted to further evaluate the association between statins and NMSC risk. In addition, basic research on cholesterol metabolism and tumor formation is needed to explore underlying mechanisms.

\section{MATERIALS AND METHODS}

This meta-analysis was conducted according to the Preferred Reporting Items for Systematic reviews and Meta-analyses (PRISMA) guidelines [27].

\section{Systematic search}

We conducted a comprehensive and systematical literature search in PubMed, EMBASE, Web of science, Cochrane Central Register of Controlled Trials (CENTRAL), and ClinicalTrials.gov registry to identify all prospective evidence (all from inception to December $11^{\text {th }}, 2016$ with no language limitation). References list from all relevant review articles, metaanalysis, and the identified articles were manually checked. The following terms were used for literature search: ((hydroxymethylglutaryl coenzyme A reductase inhibitor) OR (hydroxymethylglutaryl-coa reductase inhibitors) OR (HMG-CoA reductase inhibitors) OR (statins) OR (atorvastatin) OR (fluvastatin) OR (lovastatin) OR (mevastatin) OR (pravastatin) OR (pitavastatin) OR (rosuvastatin) OR (simvastatin) OR (cerivastatin)) AND ((melanoma) OR (non-melanoma) OR (nonmelanoma) OR (basal cell carcinoma) OR (squamous cell carcinoma) OR (cancer) OR (neoplasms) OR (neoplasm) OR (skin cancer)).

\section{Eligibility criteria}

Both randomized controlled trials and prospective observational studies (cohort study and nested casecontrol study) were considered. Included studies should meet the following criteria: (1) Published and unpublished RCTs of statins that reported NMSC cases as adverse events (length of trial $\geq 24$ weeks); (2) Cohort or nested case-control studies that examined the association between statin use and NMSC incidence; (3) All study participants were adults aged $\geq 18$ years. NMSC cases referred only to 
SCC and BCC in this meta-analysis. Retrospective casecontrol studies were excluded as they were subjected to various biases. Also, to minimize bias, we used safety data from only the original trials rather than prolonged posttrial follow-up (if available), as the majority of all subjects received open-label lipid-lowering treatment during the latter. Studies did not provide sufficient information or failed to meet eligibility criteria were also excluded.

\section{Data extraction}

Two reviewers (K.Y. and A.M.) independently performed the study selection, data extraction, and quality assessment. Numbers of NMSC cases were extracted from randomized trials and adjusted risk ratios were extracted from observational studies for data synthesis. As two included RCTs did not report NMSC events in the manuscript (JUPITER and AURORA) [11, 16], the case numbers were extracted from the "Serious Adverse Events" section on the ClinicalTrials.gov registry website. Study characteristics including first author's name, publication/report year, trial name, study design, study location, sample size, study length, type of statins, exposure and outcome assessment, as well as population characteristics including age, sex and race of the study population in each included study were also extracted.

\section{Quality assessment}

The quality of randomized trials was evaluated by Cochrane Risk of Bias (RoB) Tool [28]. We used Cochrane RoB tool to assess potential study bias in 6 domains, including random sequence generation (selection bias), allocation concealment (selection bias), blinding of participants and personnel (performance bias), blinding of outcome assessment (detection bias), incomplete outcome data (attrition bias), and selective reporting (reporting bias). The quality of included observational studies was assessed by Newcastle-Ottawa quality assessment scale (NOS) [29]. Each cohort/case-control study was evaluated on three broad perspectives: the selection of the study groups, the comparability of the groups, and the ascertainment of the exposure and the outcome of interest.

\section{Data synthesis and further analysis}

We used the random-effects model (DerSimonian and Laird inverse variance method) to estimate summary relative risk (RR) with a $95 \%$ confidence interval $(95 \%$ CI). $I^{2}$ statistics were used to assess between-study heterogeneity. Additionally, subgroup analyses were separately performed for RCTs and observational studies to explore the source of heterogeneity, based on: (1) category of statins (Lipophilic: Fluvastatin, Lovastatin, Simvastatin, Atorvastatin; Hydrophilic: Pravastatin, Rosuvastatin); (2) potency of statins (Lower: Fluvastatin, Lovastatin, Pravastatin, Simvastatin; Higher: Atorvastatin,
Rosuvastatin); and (3) duration of statin use ( $<1$ year vs. $\geq 1$ year; $<5$ years vs. $\geq 5$ years). Publication bias was examined using Begg's and Egger's tests. All statistical analyses were performed with STATA version 14.2. Twosided $\alpha \leq 0.05$ was the significance level.

\section{Abbreviations}

NMSC: non-melanoma skin cancer; BCC: basal cell carcinoma; SCC: squamous cell carcinoma; RCT: randomized controlled trial; $\mathrm{RR}$ : risk ratio; $\mathrm{CI}$ : confidence interval.

\section{CONFLICTS OF INTEREST}

None Declared.

\section{FUNDING}

None.

\section{REFERENCES}

1. Madan V, Lear JT, Szeimies RM. Non-melanoma skin cancer. Lancet. 2010; 375:673-685.

2. Lomas A, Leonardi-Bee J, Bath-Hextall F. A systematic review of worldwide incidence of nonmelanoma skin cancer. Br J Dermatol. 2012; 166:1069-1080.

3. Friis S, Poulsen AH, Johnsen SP, McLaughlin JK, Fryzek JP, Dalton SO, Sørensen HT, Olsen JH. Cancer risk among statin users: a population-based cohort study. Int J Cancer. 2005; 114:643-647.

4. Singh PP, Singh S. Statins are associated with reduced risk of gastric cancer: a systematic review and meta-analysis. Ann Oncol. 2013; 24:1721-1730.

5. Liu Y, Tang W, Wang J, Xie L, Li T, He Y, Deng Y, Peng Q, Li S, Qin X. Association between statin use and colorectal cancer risk: a meta-analysis of 42 studies. Cancer Causes Control. 2014; 25:237-249.

6. Wu QJ, Tu C, Li YY. Statin use and breast cancer survival and risk: a systematic review and meta-analysis. Oncotarget. 2015; 6:42988-43004. https://doi.org/10.18632/oncotarget.5557.

7. Bonovas S. Statins: do they have a potential role in cancer prevention and modifying cancer-related outcomes? Drugs. 2014; 74:1841-1848.

8. Scandinavian Simvastatin Survival Study Group. Randomised trial of cholesterol lowering in 4444 patients with coronary heart disease: the Scandinavian Simvastatin Survival Study (4S). Lancet. 1994; 344:1383-1389.

9. Heart Protection Study Collaborative Group. The effects of cholesterol lowering with simvastatin on causespecific mortality and on cancer incidence in 20,536 high-risk people: a randomised placebo-controlled trial [ISRCTN48489393]. BMC Med. 2005; 3:6. 
10. GISSI Prevenzione Investigators (Gruppo Italiano per lo Studio della Sopravvivenza nell'Infarto Miocardico). Results of the low-dose $(20 \mathrm{mg})$ pravastatin GISSI Prevenzione trial in 4271 patients with recent myocardial infarction: do stopped trials contribute to overall knowledge? Ital Heart J. 2000; 1:810-820.

11. Fellström BC, Jardine AG, Schmieder RE, Holdaas H, Bannister K, Beutler J, Chae DW, Chevaile A, Cobbe SM, Grönhagen-Riska C, De Lima JJ, Lins R, Mayer G, et al. Rosuvastatin and cardiovascular events in patients undergoing hemodialysis. N Engl J Med. 2009; 360:13951407. Results available at: https://clinicaltrials.gov Unique identifier: NCT00240331 (accessed December 11, 2016).

12. Stein EA, Corsini A, Gimpelewicz CR, Bortolini M, Gil M. Fluvastatin treatment is not associated with an increased incidence of cancer. Int J Clin Pract. 2006; 60:1028-1034.

13. Li X, Wu XB, Chen Q. Statin use is not associated with reduced risk of skin cancer: a meta-analysis. Br J Cancer. 2014; 110:802-807.

14. Wang A, Stefanick ML, Kapphahn K, Hedlin H, Desai M, Manson JA, Strickler H, Martin L, Wactawski-Wende J, Simon M, Tang JY. Relation of statin use with nonmelanoma skin cancer: prospective results from the Women's Health Initiative. Br J Cancer. 2016; 114:314-320.

15. Arnspang S, Pottegård A, Friis S, Clemmensen O, Andersen KE, Hallas J, Gaist D. Statin use and risk of nonmelanoma skin cancer: a nationwide study in Denmark. Br J Cancer. 2015; 112:153-156.

16. Hsia J, MacFadyen JG, Monyak J, Ridker PM. Cardiovascular event reduction and adverse events among subjects attaining low-density lipoprotein cholesterol $<50 \mathrm{mg} / \mathrm{dl}$ with rosuvastatin. The JUPITER trial (Justification for the Use of Statins in Prevention: an Intervention Trial Evaluating Rosuvastatin). J Am Coll Cardiol. 2001; 57:1666-1675. Results available at: http:// www.clinicaltrials.gov Unique identifier: NCT00239681 (accessed December 11, 2016).

17. Downs JR, Clearfield M, Tyroler HA, Whitney EJ, Kruyer W, Langendorfer A, Zagrebelsky V, Weis S, Shapiro DR, Beere PA, Gotto AM. Air Force/Texas Coronary Atherosclerosis Prevention Study (AFCAPS/TEXCAPS): additional perspectives on tolerability of long-term treatment with lovastatin. Am J Cardiol. 2001; 87:1074-1079.

18. Haukka J, Sankila R, Klaukka T, Lonnqvist J, Niskanen L, Tanskanen A, Wahlbeck K, Tiihonen J. Incidence of cancer and statin usage-record linkage study. Int J Cancer. 2010; 126:279-284.

19. Dore DD, Lapane KL, Trivedi AN, Mor V, Weinstock MA. Association between statin use and risk for keratinocyte carcinoma in the veterans affairs topical tretinoin chemoprevention trial. Ann Intern Med. 2009; 150:9-18.

20. Kuoppala J, Lamminpää A, Pukkala E. Statins and cancer: A systematic review and meta-analysis. Eur J Cancer. 2008; 44:2122-2132.

21. Hague WE, Simes J, Kirby A, Keech AC, White HD, Hunt D, Nestel PJ, Colquhoun DM, Pater H, Stewart RA, Sullivan DR, Thompson PL, West M, et al. Long-Term Effectiveness and Safety of Pravastatin in Patients With Coronary Heart Disease Sixteen Years of Follow-Up of the LIPID Study. Circulation. 2016; 133:1851-1860.

22. Goldstein MR, Mascitelli L, Pezzetta F. The double-edged sword of statin immunomosdulation. Int J Cardiol. 2009; 135:128-130.

23. Mascitelli L, Goldstein MR. Statins in dermatology: is nonmelanoma skin cancer the dark side of the moon? Int J Dermatol. 2013; 52:899-900.

24. Krynitz B, Edgren G, Lindelöf B, Baecklund E, Brattström C, Wilczek H, Smedby KE. Risk of skin cancer and other malignancies in kidney, liver, heart and lung transplant recipients 1970 to 2008 --a Swedish populationbased study. Int J Cancer. 2013; 132:1429-1438.

25. Carroll RP, Segundo DS, Hollowood K, Marafioti T, Clark TG, Harden PN, Wood KJ. Immune phenotype predicts risk for posttransplantation squamous cell carcinoma. J Am Soc Nephrol. 2010; 21:713-722.

26. Wang A, Tang JY, Stefanick ML. Relation of statin use with non-melanoma skin cancer: Prospective results from the Women's Health Initiative. Womens Health(Lond). 2016; 12:453-455.

27. Moher D, Liberati A, Tetzlaff J, Altman DG; PRISMA Group. Preferred reporting items for systematic reviews and meta-analyses: the PRISMA statement. Ann Intern Med. 2009; 151:264-269.

28. Higgins JP, Altman DG, Gøtzsche PC, Jüni P, Moher D, Oxman AD, Savovic J, Schulz KF, Weeks L, Sterne JA; Cochrane Bias Methods Group; Cochrane Statistical Methods Group. The Cochrane Collaboration's tool for assessing risk of bias in randomised trials. BMJ. 2011; 343:d5928.

29. Wells GA, Shea B, O'ConnelI D, Peterson J, Welch V, Losos M, Tugwell P. The Newcastle-Ottawa Scale (NOS) for Assessing the Quality of Nonrandomized Studies in MetaAnalyses. Ottawa Health Research Institute: Ottawa, Ontario, 2010. Available at: http://www.ohri.ca/programs/clinical epidemiology/oxford.asp (accessed December 9th, 2016). 